Available online at GSC Online Press Directory

GSC Biological and Pharmaceutical Sciences

e-ISSN: 2581-3250, CODEN (USA): GBPSC2

Journal homepage: https://www.gsconlinepress.com/journals/gscbps

(RESEARCH ARTICLE)

\title{
Studies on variation in morphological traits of mango trees (Mangifera indica) growing on Kogi State University campus, Anyigba, Kogi State, Nigeria
}

\author{
Ehoniyotan Olayemi Ibukun * and Onemayin Daniel Yomi \\ Department of Plant Science and Biotechnology, Kogi State University, Anyigba, Kogi State, Nigeria.
}

Publication history: Received on 09 April 2020; revised on 13 April 2020; accepted on 15 April 2020

Article DOI: https://doi.org/10.30574/gscbps.2020.11.1.0092

\begin{abstract}
Mango (Mangifera indica) is an economically important tropical fruit consumed all over the world due to its large fruit with a soft, sweet pulp. In this study, morphological characters of sixty (60) randomly selected mango trees growing on Kogi State University campus, Anyigba were examined. These characters were examined by comparison with those highlighted in mango descriptor by International Plant Genetic Resources Institute (IPGRI). The characters studied were crown shape, tree growth habit, leaf blade shape, leaf altitude in relation to branch, leaf apex shape, leaf margin, leaf base shape, and colour of fully developed leaf. Results revealed that $53.30 \%$ of the selected trees had broadly pyramidal crown shape; the highest percentage observed, none of the trees had spherical crown shape. There was no Drooping tree growth habit while spreading tree growth habit was the highest in $68.30 \%$ of the selected trees. Ovate, lanceolate and oblanceolate leaf blade shapes were not observed in any of the selected trees while oblong was the highest leaf blade shape observed in 50\% of the selected trees. For leaf Apex Shape; Acuminate was observed in 65\% of the selected trees, Acute in 35\% and obtuse in none of the selected trees. Most of the trees had entire leaf margin with a percentage of $98.30 \%$ of the trees having the entire leaf margin. There were morphological variations among the selected trees for all the characters studied.
\end{abstract}

Keywords: Variation; Mango; Morphological; Character; Genetic; Shape

\section{Introduction}

Mango (Mangifera indica L.) is one of the choicest fruits in the world [1]. It belongs to the family of Anacardiaceae, one of the most important species of the family and one of the most preferential fruit crops of the tropical and subtropical regions of the world for human consumption [2]. Mango (Mangifera indica) is one of the most important fruit crops of the world due to its large fruit with a soft, sweet pulp.

Due to its popularity and importance, $M$. indica is often named "King of fruits" for its luscious flavour and taste. The mango is among the widely grown tropical and subtropical fruit of the world and is a diploid fruit tree with $2 \mathrm{n}=40$ chromosomes [3]. The mango tree is an evergreen tree of varying size and shape. It has a deep taproot and profuse surface roots [4], a stout trunk (90 cm in diameter) and an umbrella-shaped crown that may reach 20-40 $\mathrm{m} \mathrm{high} \mathrm{[4,5].}$ The leaves are simple, alternate, borne on 1-12.5cm long petioles. Leaves are $16-30 \mathrm{~cm}$ long x 3-7 cm broad on flowering branches and up to $50 \mathrm{~cm}$ long on sterile branches. Young leaves are orange-red and turn shiny dark green on the upper surface when they mature.

The edges of the leaves are somewhat wavy. Mango tree flowers are fragrant, pentameric, greenish-white or pinkish, very small (3-5 mm long x 1-1.5 mm broad) and densely borne on $30 \mathrm{~cm}$ long, pyramidal panicles [4, 5]. Morphological variations of mango varieties have been studied extensively [6,7]. Detailed descriptions of mango cultivars are available in the publications of Knight et al [8]. Levels in variation amongst types of mango are being studied via morphological

\footnotetext{
* Corresponding author: Ehoniyotan Olayemi Ibukun
} 
characterization of qualitative and quantitative characters [9, 10]; iso-enzymatic [11], and molecular by using different types of markers, like RAPD $[12,13]$. Differentiation between types of mango has been done by characters associated with yielding components; that is, fruit size and weight, flesh and fiber content [14] and fruit shape- aroma [15]. Despite its popularity, limited scientific attention has been directed towards the characterization of the numerous cultivars found in Nigeria [16].

Morphological characterization is the first step that should be done before more profound biochemical or molecular studies are carried out [17]. The evaluation of morphological and agronomic characters can provide relevant information on yield and quality traits, as well as other information of great interest to breeders, such as descriptions of available variation and estimates of trait heritability [18]. Thus, this study was carried out to observe the Morphological Variations among mango trees growing on Kogi State University Campus, Anyigba.

\section{Material and methods}

\subsection{Study Area and map}

The study area is located on latitude $7049 \mathrm{~N}$ and longitude 7018E. Anyigba is located at Eastern part of Kogi State in Dekina local government area. Anyigba lies between latitude 7015-7029 N and longitude 7011-7032 N and with average altitude of 420 meters above sea level. The study area falls within the tropical wet and dry climate region and the guinea savanna, with mean annual temperature of $250 \mathrm{C}$ and rainfall $1600 \mathrm{~mm}$.

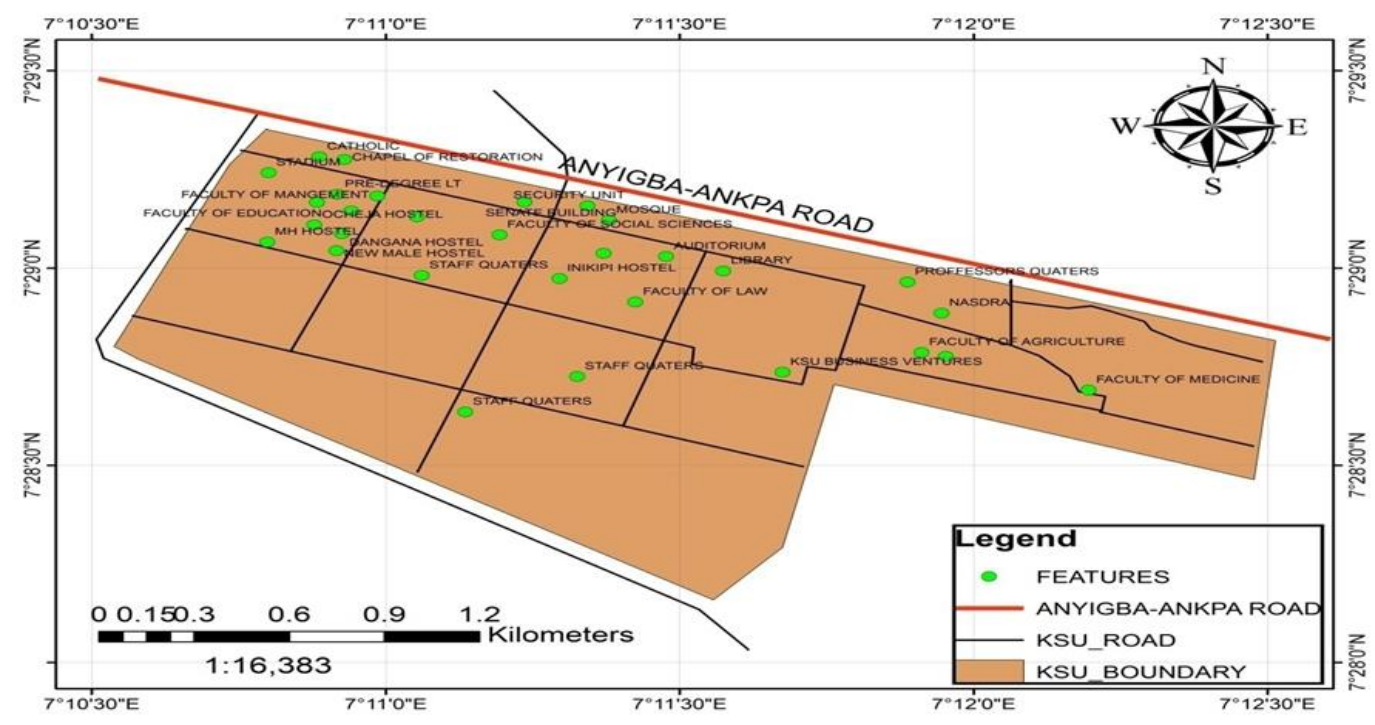

Figure 1 Map of Kogi State University, Anyigba. Source: Department of Geography, KSU, Anyigba.

\subsection{Material used}

Tags, nail, hammer, marker, nylon bag and paper.

\subsection{Method}

Sixty (60) randomly selected trees of Magnifera indica were tagged with alphabets A1-A60

\subsection{Data collection}

Data were collected from the tagged trees and the following data were collected.

\subsubsection{Crown shape}

The crown shape of each selected tree was observed directly on the field and compared with shapes in cashew descriptors by International Plant Genetic Resources Institute [19]. 


\subsubsection{Tree growth habit}

The tree growth habit of the selected trees were observed directly on the field and compared to tree growth habit by International Plant Genetic Resources Institute.

\subsubsection{Leaf blade}

The leaf blade of each tree was identified by comparing with leaf shapes in mango descriptor by the International Plant Genetic Resources Institute [19].

\subsubsection{Leaf attitude in relation to branch}

The leaf attitude in relation to branch of each tree was identified by comparing with leaf attitude in mango descriptor by the International Plant Genetic Resources Institute [19].

\subsubsection{Leaf apex shape}

The leaf apex shape of each tree was identified by comparing with leaf apex shape in mango descriptor by the International Plant Genetic Resources Institute [19].

\subsubsection{Leaf base shape}

The leaf base shape of each tree was identified by comparing with leaf base shape in mango descriptor by the International Plant Genetic Resources Institute [19].

\subsubsection{Leaf margin}

The leaf margin of each tree was identified by comparing with leaf margin in mango descriptor by the International Plant Genetic Resources Institute [19].

\subsubsection{Colour of matured leaves}

The colour of matured leaves of each tree was observed using colours of matured leaves in mango descriptor by the International Plant Genetic Resources Institute [19] as a guide.

\section{Results and discussion}

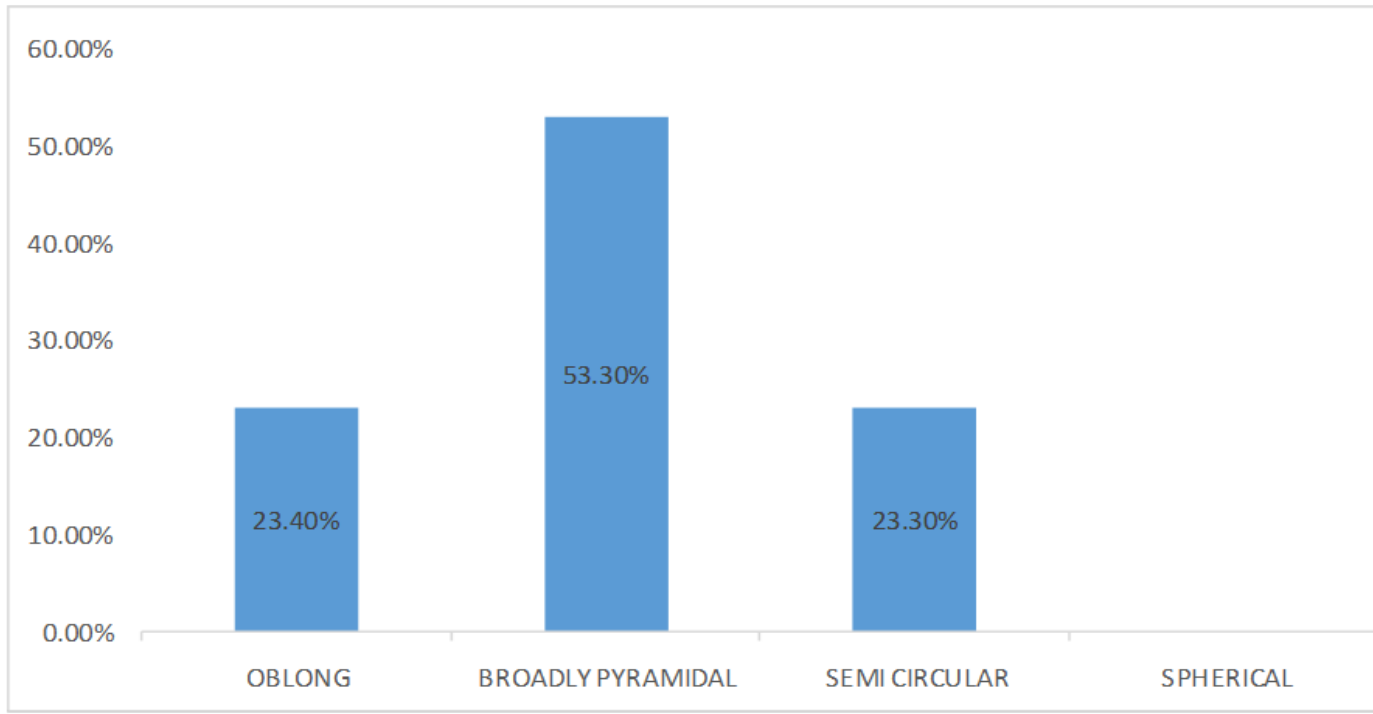

Figure 2 Percentages of Crown shapes observed in the selected trees

The percentages of crown shapes of the selected trees presented in Figure 2 indicates broadly pyramidal to be the most observed crown shape in $53.30 \%$ of the selected trees and this was similar to an earlier report by [20]. The Oblong and Simi-circular crown shapes were observed in $23.40 \%$ and $23.30 \%$ of the selected trees respectively while none of the selected tree was observed to have spherical crown shape. 


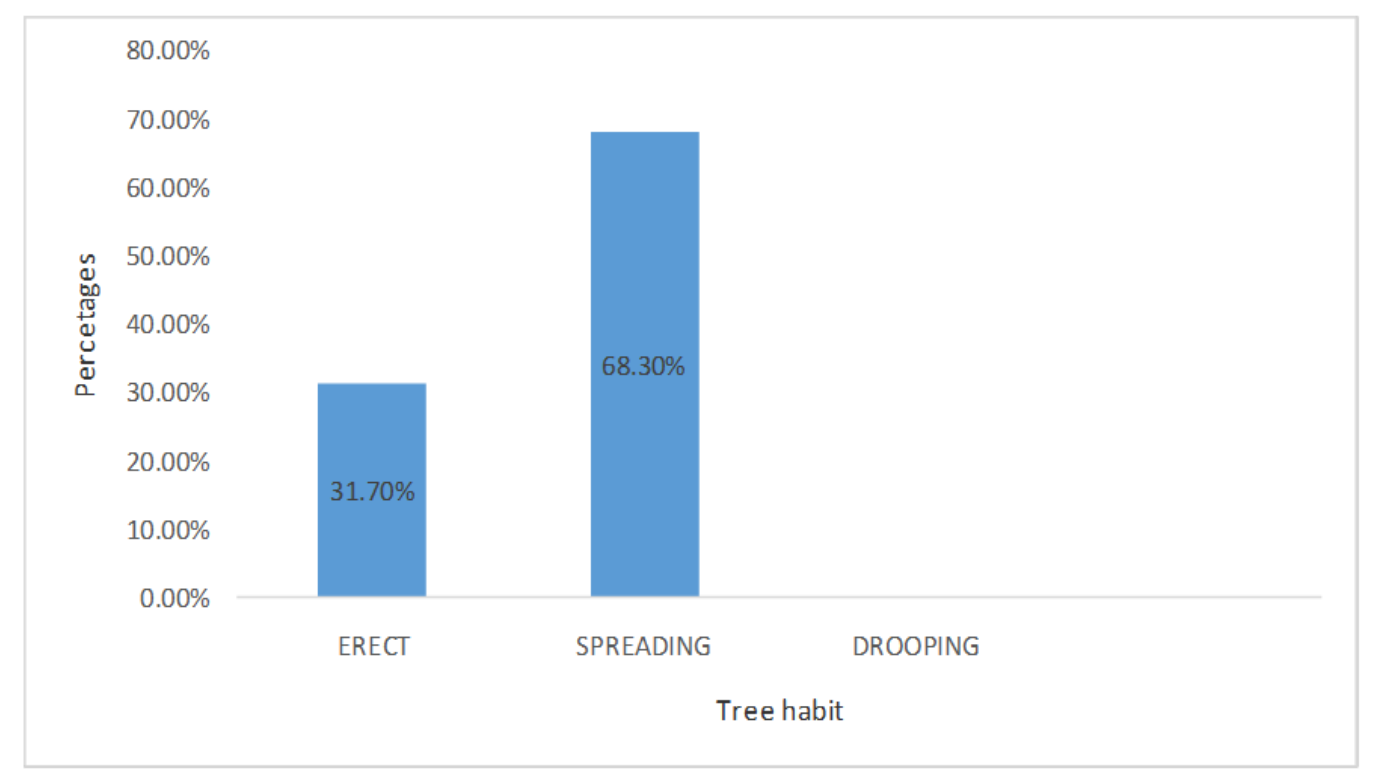

Figure 3 Percentages of tree growth habits observed in the selected trees

The tree growth habit result presented in Figure 3 shows that spreading tree habit was the most observed in $68.30 \%$ of the selected trees. The result is in agreement with a similar work by [21] on mango who reported that the highest tree growth habit was spreading with $65.1 \%$. The erect tree growth habit was observed in $31.70 \%$ of the selected tree while none of the selected tree had the drooping tree growth habit.

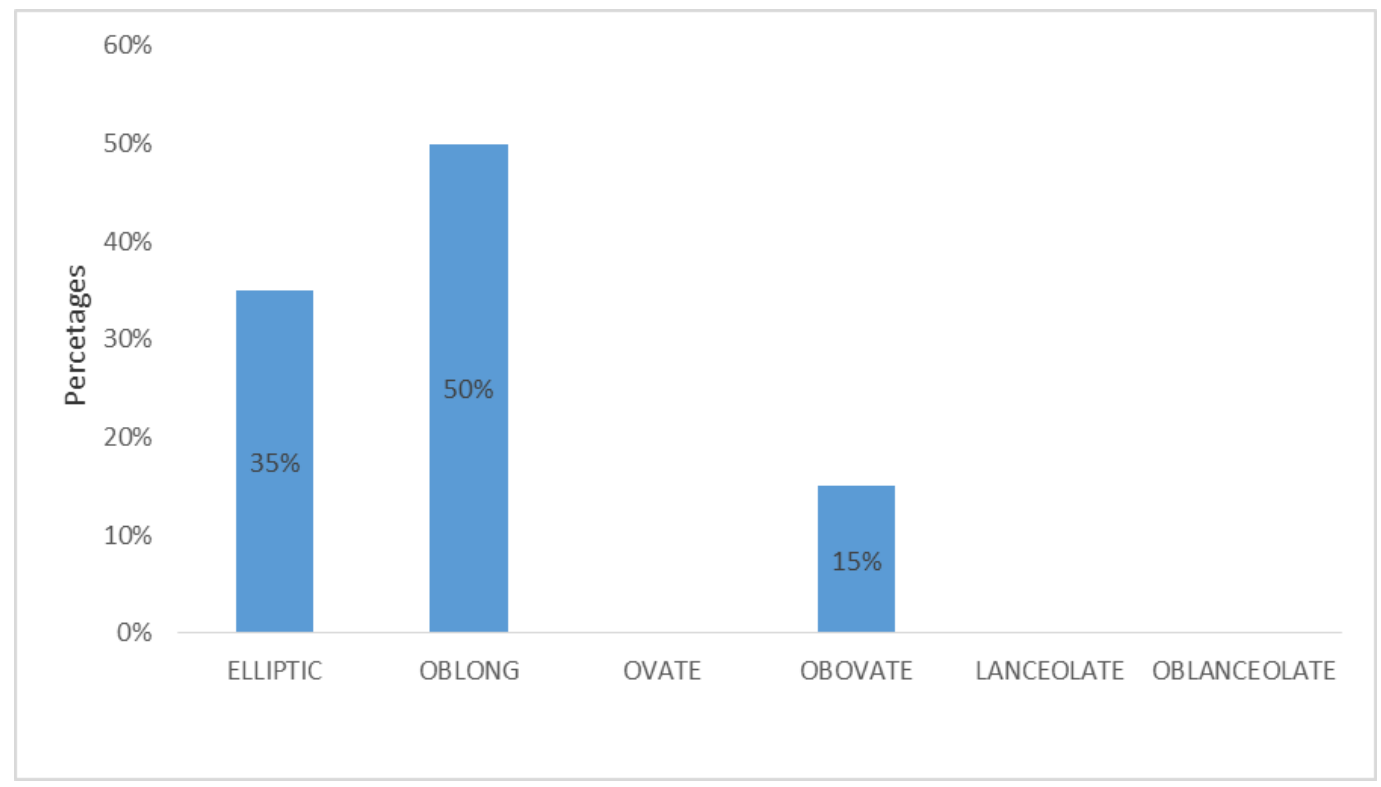

Figure 4 Percentages of leaf blade shapes observed in the selected trees

The blade shape presented in Figure 4 shows oblong leaf shape to be the highest observed in $50 \%$ of the selected trees followed by elliptical in 35\% of the selected trees. Toili et al. [21] reported elliptical to be the highest (62.8\%) observed leaf blade shape in a similar study on mango. Ovate, lanceolate and oblanceolate leaf blade shapes were not observed in any of the selected mango trees. 
Ehoniyotan and Onemayin / GSC Biological and Pharmaceutical Sciences, 2020, 11(01), 113-120

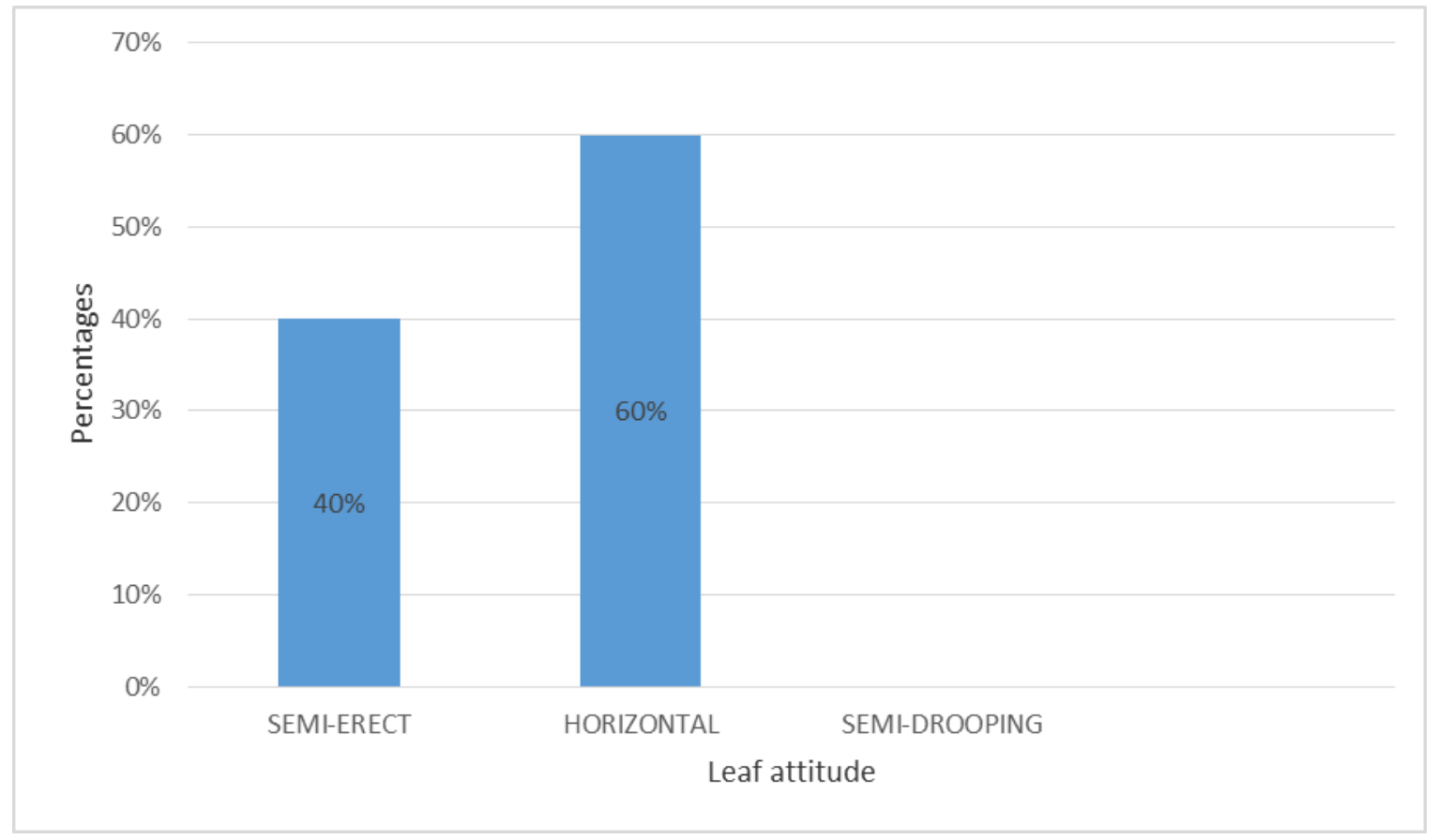

Figure 5 Percentages of Leaf attitude in relation to branch of the selected trees

Result for leaf attitude in relation to branch presented in Figure 5 shows the horizontal leaf attitude to be the most observed with $60 \%$ of the selected trees possessing this attitude. The semi-drooping leaf attitude in relation to branch was not observed in any of the selected trees and this was also reported by [21] in their work on mango.

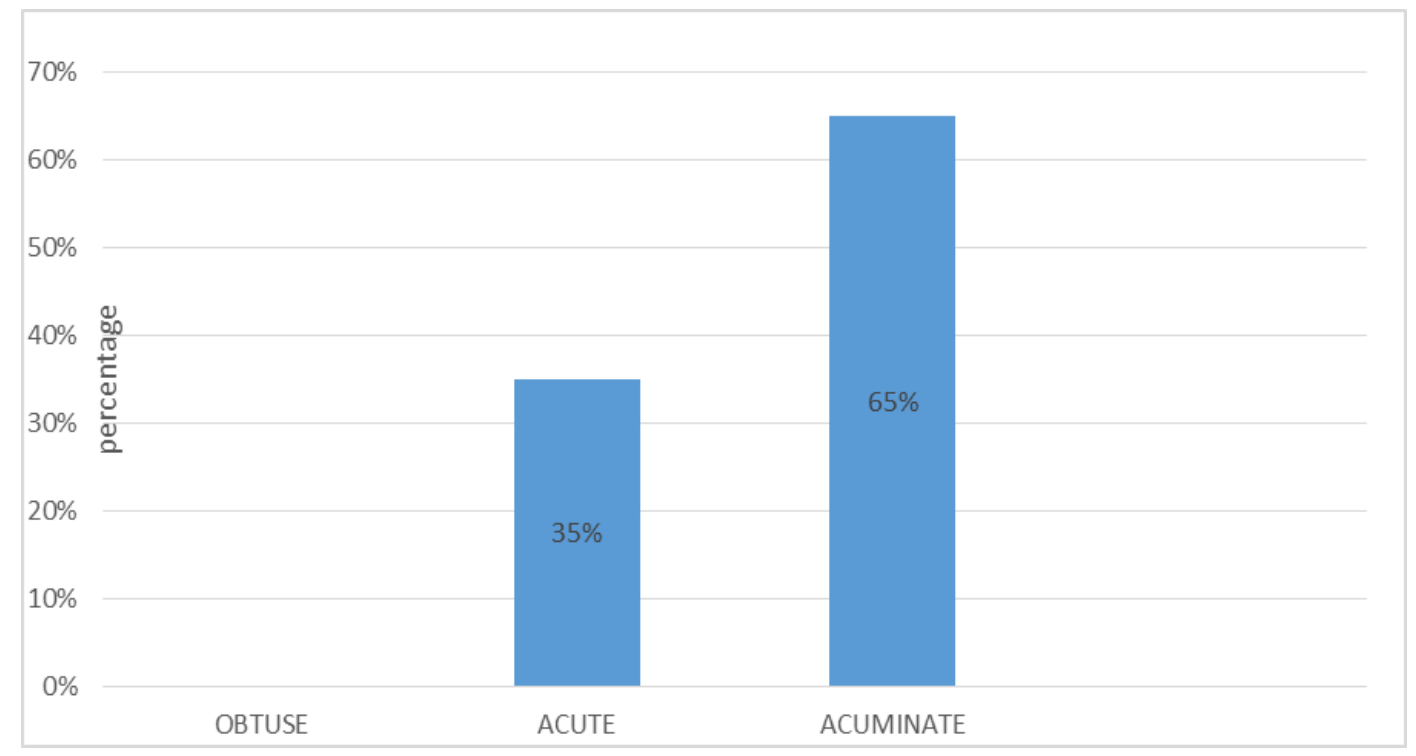

Figure 6 Percentages of Leaf apex shape of the selected trees

The leaf apex shapes presented in Figure 6 reveals acuminate to be the most observed leaf apex shape with $65 \%$ of the selected trees while acute was observed in $35 \%$ of the selected trees. The obtuse leaf apex shape was not observed in any of the selected trees. 
Ehoniyotan and Onemayin / GSC Biological and Pharmaceutical Sciences, 2020, 11(01), 113-120

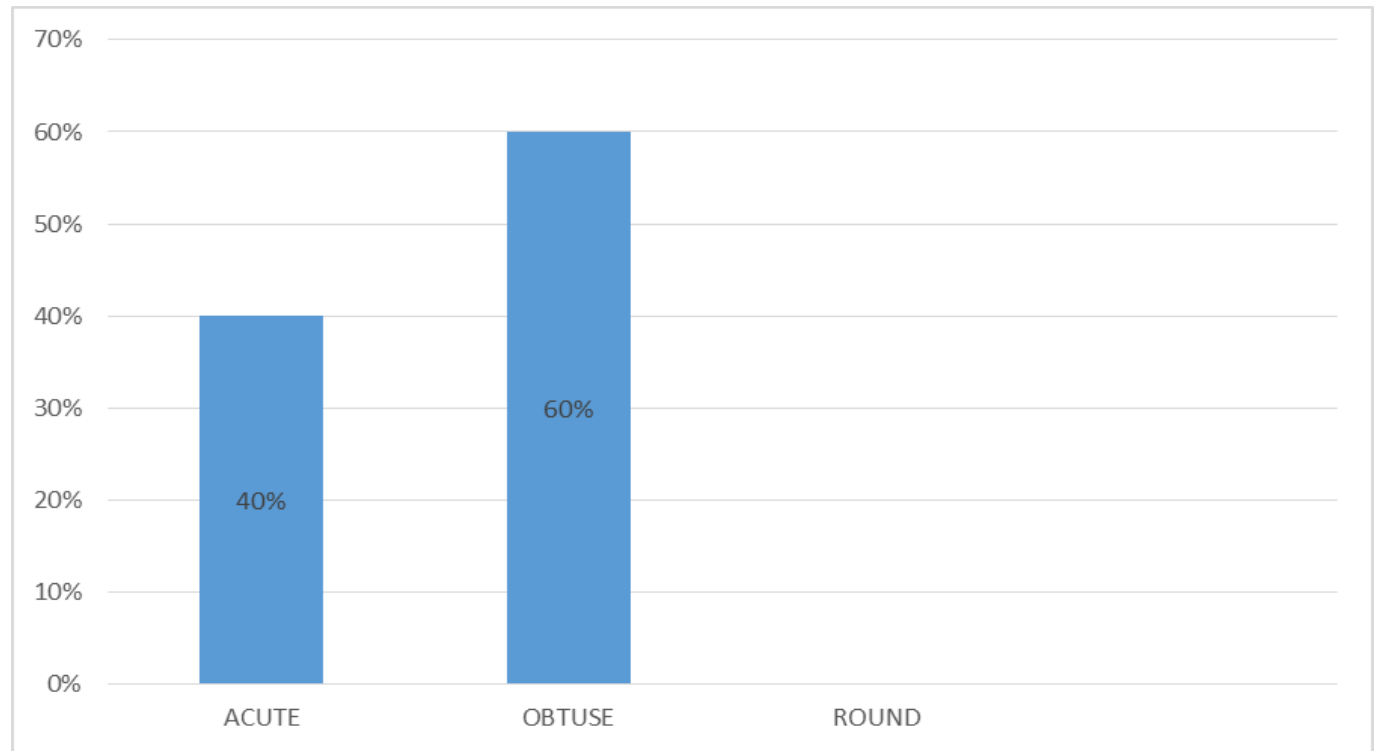

Figure 7 Percentages of Leaf base shape of the selected trees

Result of leaf base shape presented in Figure 7 shows that the most observed leaf base shape was obtuse in $60 \%$ of the selected trees. The result was similar with earlier report by [21] who also reported $84.9 \%$ obtuse leaf base shape in their work on mango. The round leaf base shape was not observed in any of the selected trees.

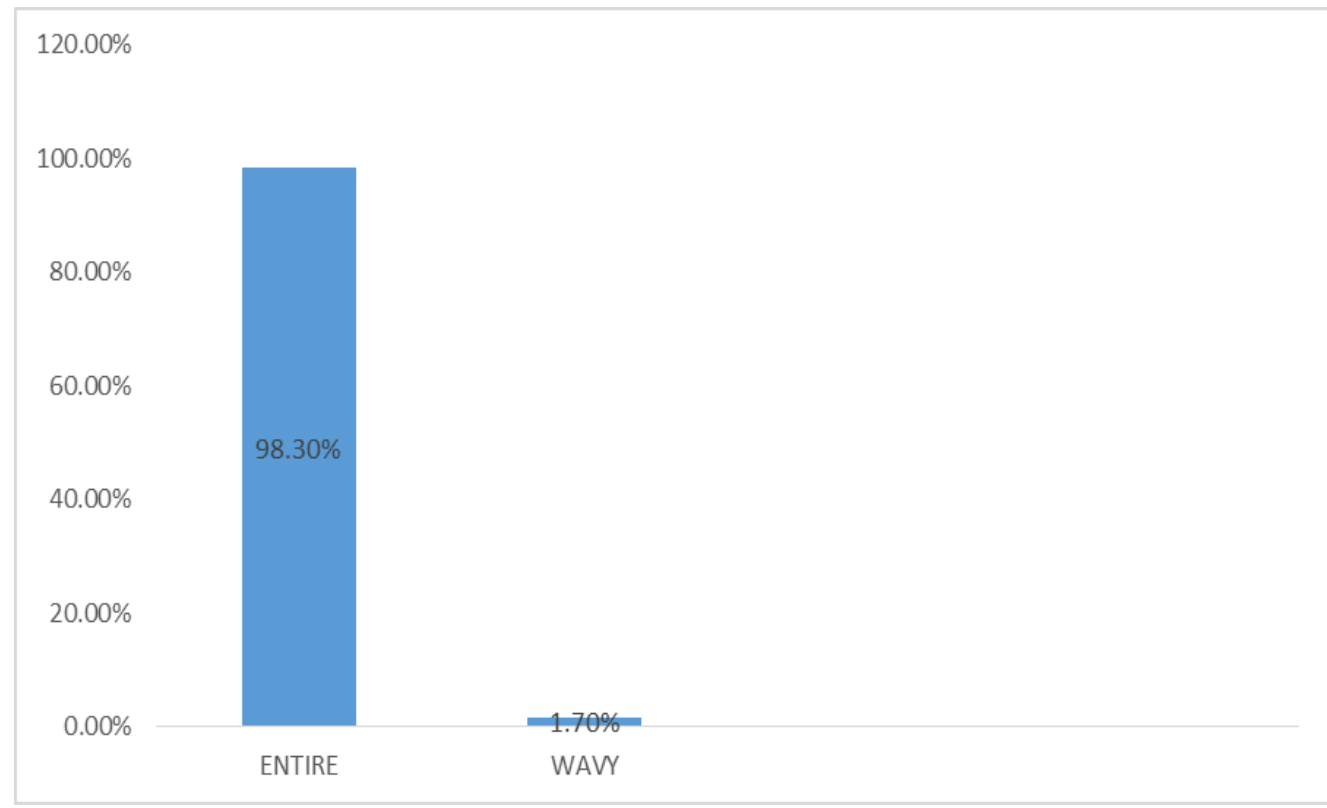

Figure 8 Percentages of Leaf margin of the selected trees

The result of leaf margin presented in Figure 8 shows that the entire leaf margin was observed in $98.30 \%$ of the selected trees and this is similar to the work of [21] who reported $77.9 \%$ for entire leaf margin. Kanchan et al [20] also reported to have observed the entire leaf margin in 21 genotype of the 24 genotype they studied. 


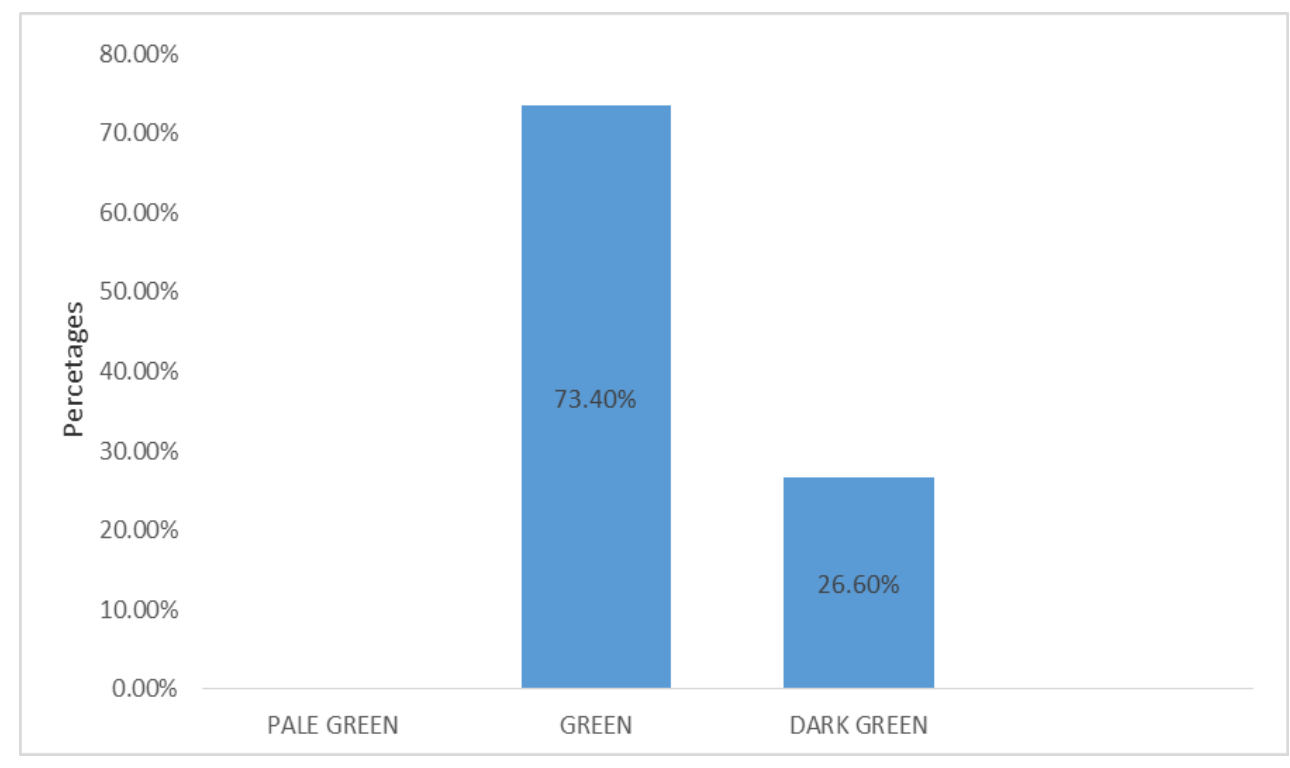

Figure 9 Percentages of Colour of matured leaves of the selected trees.

The colour of matured leaves presented in Figure 9 showed that $73.40 \%$ of the selected trees had green matured leaves while $26.60 \%$ of the selected tree had dark green mature leaves. This result is consistent with kanchan et al [20] who reported green mature leave in 20 out of 24 genotypes studied. However in this work, the pale-green mature leaf was not observed in any of the selected trees.

\section{Conclusion}

This study has revealed and provided the morphological variations that exist in mango trees growing on the University campus. The evaluation of morphological variations obtained in this present study may be of help to breeders for various genetic breeding programs in mango cultivars and also serve as a baseline for further study on mango in the area. However, to confirm whether the variations are genetic in nature there is need for characterization using molecular markers.

\section{Compliance with ethical standards}

\section{Acknowledgments}

Special appreciations to Falaiye, Oluwabiyi Titus and Late Abimaje Gift who assisted with the data collection.

\section{Disclosure of conflict of interest}

There is no conflict of interest.

\section{References}

[1] Joshi R, Kundu M and Singh CP. (2013). Morphological Characters: Efficient Tool for Identification on Different Mango Cultivars. Environment and Ecology, 31(1A), 385-388.

[2] Vasugi C, Dinesh MR, Sekar K, Shivashankara KS, Padmakar B and Ravishankar KV. (2012). Genetic diversity in unique indigenous mango accessions (Apemidi) of the Western Ghats for certain fruit characteristics. Current Science, 103(2), 19.

[3] Kuhn DN, Bally ISE, Dillon NL, Innes D, Groh AM, Rahaman J, Ophir R, Cohen Y and Sherman A. (2017). Genetic Map of Mango: A Tool for Mango Breeding. Front. Plant Science, 8, 577.

[4] Litz RE. (2009). The Mango. Botany, Production and uses. 2nd edn. CAB international, Wallingford, USA, 680.

[5] Orwa C, Mutua A, Kindt R, Jamnadass R and Simons A. (2009). Agroforestree Database: a tree reference and selection guide version 4.0. World Agroforestry Centre. 
[6] Gálvez-López D, Salvador-Figueroa M, Adriano-Anaya MDL and Mayek-Pérez N. (2010). Morphological characterization of native mangos from Chiapas, Mexico. Subtropical Plant Science, 62, 18-26.

[7] Mohamed ZMA and Ahmed THM. (2015). Diversity of Mango (Mangifera indica L.) Cultivars in Shendi Area: Morphological Leaf Characterization. International Journal of Research on Agricultural Science, 2(4), 2348 3997.

[8] Knight RJ, Campbell RJ and Maguire I. (2009). Important mango cultivars and their descriptors. In: Litz RE (ed) The Mango Botany, Production and Uses. 2nd edn. CAB International, UK.

[9] Subedi A, Bajravharya J, Joshi BK, Regmi HN, Gupta SR and Hari BKC. (2004). Characterization and genetic diversity of mango (Mangifera indica L.) in Nepal. In: On-farm Conservation of Agricultural Biodiversity in Nepal. Volume I. Assessing the Amount and Distribution of Genetic Diversity on-farm. B.R. Sthapit MP. z Upadhyay, P.K. Shrestha, D.I. Jarvis (Eds.). IPGRI. Proceedings of the Second National Workshop. Nagarkot, Nepal, 191.

[10] Bally ISE. (2011). Advances in research and development of mango industry. Revista Brasileira de Fruticultura, 33, 57-63.

[11] Gálvez-López D, Adriano-Anaya ML, Villarreal-Treviño C, Mayek-Pérez N and Salvador-Figueroa M. (2007). Diversidad isoenzimática de mangos criollos de Chiapas, México. Rev. Chapingo. Serie Horticultura, 13(1), 71 - 76.

[12] Ravishankar KV, Lalitha A, Dinesh MR and Anand L. (2000). Assessment of genetic relatedness among mango cultivars of India using RAPD markers. Journal of Horticultural Science and Biotechnology, 75(2), $198-201$.

[13] Anju B, Navin S, Rajan S and Chandra RS. (2008). Genetic diversity and discrimination of mango accessions using RAPD and ISSR markers. Indian Journal of Horticulture, 65, 377-382.

[14] Rajan S, Yadava LP, Ram K and Saxena SK. (2009). Genetic divergence in mango varieties and possible use in breeding. Indian Journal of Horticulture, 66(1), 7-12.

[15] Sagar SP, Chidley HG, Kulkarni RS, Pujari KH, Giri AP and Gupta VS. (2009). Cultivar relationships in mango based on fruit volatile profiles. Food Chemistry, 114(1), 363-372.

[16] Aguoru CU, Okoli BE and Olasan JO. (2016). Taxonomic investigation of four cultivars of mangifera using microanatomical features. International Research Journal of Natural Sciences, 3(5), 21-32.

[17] Hoogendijk M and Williams D. (2001). Characterizing the genetic diversity of home garden crops: Some examples from Americas. 2nd International Home gardens workshop, 17-19 July 2001, Witzenhausen, Federal Republic of Germany, 34-40.

[18] Anumalla M, Roychowdhury R, Geda CK, Mazid M and Rathoure AK. (2015). Utilization of plant genetic resources and diversity analysis tools for sustainable crop improvement with special emphasis on Rice. International Journal of Advanced Research, 3(3), 1155-1175.

[19] IPGRI. (2006). Descriptors for Mango (Mangifera indica L.). International Plant Genetic Resources Institute, Rome, Italy.

[20] Kanchan B, Anjani-Kumar US, Jaiswal Md, Feza A and Ruby R. (2018). Morphological Characterization of Mango (Mangifera indica L.) Germplasm Using DUS Testing. International Journal of Curricular Microbiology and Applied Sciences, 7(05), 2944-2959.

[21] Toili MEM, Aunberia FK, Nyende AB and Sila D. (2016). Morphological Diversity of Mango Germplasm From the Upper Piller Region of Eastern Kenya: An Analysis Based on Alen-Fruits Descriptors. African Journal of Food, Agriculture, Nutrition and Development, 16(2), 10918-10918.

\section{How to cite this article}

Ehoniyotan OI and Onemayin DY. (2020 Studies on variation in morphological traits of mango trees (Mangifera indica) growing on Kogi State University campus, Anyigba, Kogi State, Nigeria. GSC Biological and Pharmaceutical Sciences, 11(1), 113-120. 